\title{
The Application of Mobile Devices in the Translation Classroom
}

\author{
Hossein Bahri (Corresponding author) \\ School of Languages, Literacies and Translation, Universiti Sains Malaysia, Malaysia \\ E-mail: hobahri@yahoo.com \\ Tengku Sepora Tengku Mahadi \\ School of Languages, Literacies and Translation, Universiti Sains Malaysia, Malaysia
}

Doi:10.7575/aiac.alls.v.7n.6p.237

URL: http://dx.doi.org/10.7575/aiac.alls.v.7n.6p.237
Received: 20/10/2016

Accepted: $28 / 11 / 2016$

\begin{abstract}
While the presence of mobile electronic devices in the classroom has posed real challenges to instructors, a growing number of teachers believe they should seize the chance to improve the quality of instruction. The advent of new mobile technologies (laptops, smartphones, tablets, etc.) in the translation classroom has opened up new opportunities for translator trainers to facilitate the process of translator education. The present paper investigates the use of mobile devices in the classroom particularly for translation pedagogy. A focus group interview of translation instructors with experience in using mobile tools in their translation classes was followed by a survey sent to a group of English $<>$ Persian translation instructors of which 26 people filled out the questionnaire completely. The participants of the study provided both qualitative and quantitative data regarding the application of mobile devices in their translation classes. The results showed that the majority of teachers encouraged their advanced level students to use mobile tools for doing classroom assignments followed by note-taking, using terminology databases, searching the Internet, using language resources and contacting their group members. The findings highlight the potentials of mobile devices to have a positive impact on the translation classroom activities and underline the need for their systematic integration into the translation curriculum as part of the tools contributing to the development of technological competence.
\end{abstract}

Keywords: application, mobile devices, translation classroom, translator education

\section{Introduction}

The widespread nonacademic use of mobile devices such as the common cell phone in college classrooms is a real challenge to educators. Research on the application of mobile digital tools (laptops, smartphones, tablets, etc.) in the classroom has sometimes yielded conflicting results depending on the devices under investigation, types of users, and the learning context and situation. Whereas some studies have found negative (Jacobson \& Forste, 2011; Lepp et al., 2015; Sanchez-Martinez \& Otero, 2009) or even ambivalent (Lam \& Tong, 2012) relationships between students' frequent use of digital devices (mostly cell phones) in the classroom and their academic performance, the application of these devices to support learning is increasingly becoming more popular in many universities and colleges. For example, Yeshi \& Aagard (2011) reviewed literature on the use of cell phones for college teaching and found that the majority of studies supported their application to enhance students' learning and interaction even though they acknowledged the existence of some limitations.

In another study Foti \& Mendez (2014) found that the majority of university students used their mobile devices to support learning even when they were out of their classes. Students also utilized their mobile tools to enhance their 'role' as active responsible students when they communicated with the teachers conveniently through their emails (ibid).

The results of a Pearson Education (2015) survey showed that the rate of device ownership and device usage were almost the same. Therefore, more institutions advise teachers to adopt the policy of BYOD (Bring Your Own Device) so that the use of technology in class becomes less expensive for the institution and more feasible for both students and teachers (ibid). It was also found that $87 \%$ of students owned/used laptops for college work followed by $64 \%$ using smartphones and $40 \%$ using tablets for the purpose of learning. Students stated that they learnt best on laptops $54 \%$ followed by tablets $16 \%$ and smartphones $11 \%$. Nine percent said they learnt the same on any of the mentioned devices while 5\% said they did not learn well on any of the tools. Moreover, the majority of students - in fact 59\% of students who owned a tablet and 54\% who owned a smartphone - mentioned that they used learning apps on their devices (ibid). An app is a type of specific software which enables mobile devices to overcome their physical/digital constraints (e.g. small screen size or limited processing power).

In an effort to examine the effects of texting, Twitter and message content on student learning while using mobile phones in the classroom, Kuznekoff et al. (2015) conducted a study of eight experimental groups and one control group who watched a video lecture, took notes and did a test on their learning. The results showed that students' sending and 
receiving of messages unrelated to the classroom content had a negative impact on their learning and note taking whereas relevant messages did not significantly have a negative impact. Their research stresses the importance of the relevance of mobile devices' classroom application to the activities engaged in class.

Furthermore, a study of an Australian regional university by Farley et al (2015: 6) revealed that students actively used mobile technologies such as laptops and tablets even more than desktop computers to support their studies followed by smartphones and netbooks.

In connection with the teaching of translation, Farley et al (2015: 10) reported the findings of their research which showed that many students at the University of Southern Queensland frequently used their mobile apps in the classroom for language learning or translation purposes. In fact, these days mobile devices are acting as the toolboxes of modernday translators. A cursory search on the Internet reveals that there are many free apps available for doing translation tasks (e.g. Google Translate, iTranslate, Waygo, iHandy, Voice Translator, SMS Translator, iTranslate Voice, Languages, Speak Text, SayHi Translate, iPro Translate, Voice Translate Pro, MyLanguage Translator Pro, Pixter Scanner OCR, etc. are just to name a few). These apps are only workable when they are installed on the translators' toolboxes, i.e. their mobile devices.

\subsection{The Development of Technological Competence for Translators}

Today there is a consensus among translation scholars that translators need to have expert knowledge and skills in some areas and activities to do translation tasks and projects. In other words, they need to have competence for performing the act of translation (Schäffner \& Adab, 2000: viii). Within the last four decades many scholars have defined translation competence based on different approaches to translation activity (performance). Most of these proposals are based on 'multi-componential models' that regard the translation process as a combination of complex, multifarious and interrelated activities requiring mastery of several skills and abilities.

Therefore, after considering all types of competences defined by researchers and labeled as 'technical', 'instrumental', or 'technological' (e.g., Roberts 1984: 172; PACTE Group 2000, 2003, 2005, 2007, 2011; Kelly 2005: 32; Alcina 2008: 96; and the EMT Expert Group, 2009, http://ec.europa.eu/emt) we decided to summarize all available definitions of technological competence for the sake of relevance, ease of comparison and reference as shown by their goals in table 1 below.

Table 1. Overall Goals of Technological Competence as Defined by Different Researchers

Roberts (1984)

Technical Competence

- Knowing how to use various translation aids, e.g. word processing, terminology databases, etc.
PACTE Group (20002011, under Hurtado) Instrumental Competence
- Knowing how to use documentation resources and information and communication technologies applied to translation: dictionaries of all kinds, encyclopedias, grammars, style books, parallel texts, electronic corpora, searchers, etc.
Kelly (2005)

Instrumental as part of

the Professional and

Instrumental

Competence
- Knowing how to use documentary resources of all kinds, terminological research, information management for these purposes, use of IT tools for professional practice (word-processing, desktop publishing, databases, Internet, email ...) together with more traditional tools such as fax, Dictaphone, etc.

\section{Alcina (2008) \\ Instrumental \\ Competence}

- Knowing how to use the translator's computer equipment (e.g. operating systems, computer maintenance software, information support and backup, hardware, drives, etc.).

- Knowing how to use communication and documentation tools (e.g. interaction and networking tools, bibliographic databases, online encyclopedias, university websites, email, chat, videoconferencing software, mail lists, and virtual collaborative work environments).

- Knowing how to use text edition and desk-top publishing tools (e.g. word processors, HTML and/or XML editors, web-design applications, pdf to txt convertors).

- Knowing how to use language tools and resources (e.g. tools like Multiterm and WordSmith and resources like Eurodicautom and Termium).

- Knowing how to use translation tools (e.g. all translation memory management software, machine translation tools, localization tools, audiovisual translation tools, etc). 
The EMT Expert

Group, (2009, under

Yves Gambier), http://ec.europa.eu/emt

Technological

Competence
- Knowing how to use effectively and rapidly and to integrate a range of software to assist in correction, translation, terminology, layout, documentary research (for example text processing, spell and grammar check, the Internet, translation memory, terminology database, voice recognition software).

- Knowing how to create and manage a database and files.

- Knowing how to adapt to and familiarize oneself with new tools, particularly for the translation of multimedia and audiovisual material.

- Knowing how to prepare and produce a translation in different formats and for different technical media.

- Knowing the possibilities and limits of MT.

A glance at table 1 above shows that most definitions do not specifically refer to mobile devices, except for Alcina's (2008) definition that mentions 'translator's computer equipment (i.e. hardware)', which can potentially include mobile devices. This highlights the need for more research on the application and subsequent integration of mobile tools into the current technological competence models. The first objective of such research should be 'to describe how mobile devices can be used for teaching translation classes' and then 'to find out what types of classroom activities involving the application of mobile devices are mostly encouraged by translation instructors.' With regard to the above mentioned objectives the following research questions were investigated:

1. How can mobile devices be used for teaching translation classes?

2. What types of classroom activities involving the application of mobile devices are mostly encouraged by translation instructors?

\section{Method}

Based on the research questions the researchers adopted mixed methods design (qual $\rightarrow$ QUAN) for the present study (Dörnyei, 2007: 171). A small-scale exploratory qualitative study - a focus group interview including 4 participating teachers with at least 5 years experience in using mobile devices for teaching translation - was conducted to provide the essential information and practical ideas for answering the first research question and for preparing a questionnaire, which was later used to answer the second research question. Subsequently, the researchers of the study developed the instrument and sent it to 65 English $<>$ Persian translation instructors of which 26 participants reported they had at least 3 years of translation teaching experience using various electronic and mobile tools and returned the questionnaire after filling it out completely. The participants were asked to fill out the 12-item instrument, which was developed based on a Likert scale and mostly asked the participants about their preferences for the types of classroom activities involving the application of mobile devices mostly encouraged by translation teachers. This, in turn would provide a framework for identifying the priorities of the activities involving the application of mobile devices in the translation classes. Hence, the study relied on both qualitative and quantitative data for interpretation of the results. The collected information was analyzed using PASW Statistics software (SPSS) version 18 for descriptive statistics. The average coefficient of reliability (Cronbach's Alpha) for the internal consistency of questionnaire items was 0.754 , which indicated reasonably high reliability of the instrument.

\section{Results}

The results of the qualitative content analysis of the focus group interview with four participating instructors provided us with many themes and practical information concerning how mobile devices can be used for teaching translation classes. The following excerpts were transcribed from the recording of the discussions:

Teacher A: “... I believe that mobile devices can be vital tools if students mostly use them for doing their tasks and assignments. .... nowadays students do not bring traditional dictionaries and reference books to classroom .... You know, it takes much more time to look up words in dictionaries; that's why they are such voluminous heavy burdens ... and now students feel [there is] no need to look up words in such time-consuming references...Advanced level students can also find many authentic examples and use online terminology databases provided that they know how to search effectively..."

Teacher B: “... well, I think there are a lot of opportunities in using mobile devices in the classroom. One is to do classroom tasks as [teacher A] mentioned. Number two is to keep records, such as while they are taking notes and at the same time listening to the teacher or simply audio-record the discussions ... [this is] what I've noticed they frequently do in my classes. Sometimes I ask them to search the Internet to find [the meaning of] some special words that have not been added to the lexicon such as many media coinages, colloquialisms, neologisms, etc. ..."

Teacher C: “... I think mobile devices can be very useful only if students follow classroom rules and use them appropriately, and I believe it is the job of the teacher to set rules and teach students how to use these devices effectively. For example, she can advise advanced level students to use online terminology databases or use online language resources because updating one's language proficiency is a constant requirement for translators....I believe that the type of the device should also be considered... will laptops better serve the teaching purpose than, say, tablets?"

Teacher D: “... what I think was just briefly mentioned in our discussion is the students' tendency to contact their friends on the social media through their mobile devices, which can potentially be encouraged by the teacher [to use the 
habit] for contacting their [academic/classroom] group members... This can associate the application of the device with more relevant and useful academic activities..."

Following our small-scale focus group interview we extracted some themes (typed in bold letters above) for potential activities that teachers can encourage in their translation classes. Later on these themes were used to develop a questionnaire, which was used to answer the second research question. Table 2 below summarizes the typology of activities and tools encouraged by translation instructors. The results show that the following types of activities are mostly preferred by the participating instructors based on their priorities:

Doing classroom assignments - The findings of the study suggest that most instructors $71 \%$ encouraged the use of mobile devices as students' primary tool of reference for doing their classroom projects and tasks.

Note-taking - Many translation teachers $68 \%$ stated that they also encouraged the use of mobile devices for note-taking in their classes.

Using terminology databases - Again, the majority of translation instructors $65 \%$ mentioned that they encouraged the use of mobile devices for using terminology databases in their classes.

Searching the Internet - Currently many of mobile devices are efficient tools to search the Internet and hence $62 \%$ of translation instructors recommended them for this type of activity in the classrooms.

Using language resources - Sixty percent of the participants encouraged the use of language resources through the medium of mobile devices in the classroom.

Contacting group members - This was the area for which only $44 \%$ - less than half - of translation teachers believed that students could use their mobile devices in their classes.

Table 2. Typology of Activities and Tools Encouraged by Translation Instructors

\begin{tabular}{lcc}
\hline Typology of Activities/ Mobile Devices & Discouraged & Encouraged \\
\hline Doing classroom assignments & $29 \%$ & $71 \%$ \\
\hline Note-taking & $32 \%$ & $68 \%$ \\
\hline Using terminology databases & $35 \%$ & $65 \%$ \\
\hline Searching the Internet & $38 \%$ & $62 \%$ \\
\hline Using language resources & $40 \%$ & $60 \%$ \\
\hline Contacting group members & $56 \%$ & $44 \%$ \\
\hline Laptops & $14 \%$ & $86 \%$ \\
\hline Tablets & $37 \%$ & $63 \%$ \\
\hline Cell Phones & $48 \%$ & $52 \%$ \\
\hline Operating Microsoft Windows & $27 \%$ & $73 \%$ \\
\hline Operating Google Android & $31 \%$ & $69 \%$ \\
\hline Operating Apple iOS & $77 \%$ & $23 \%$ \\
\hline Participants(total)=26 & & \\
\hline
\end{tabular}

Among the three types of tools (i.e. mobile devices) investigated, the majority of teachers preferred laptops $86 \%$ to tablets $63 \%$ followed by cell phones; only $52 \%$. Most instructors, $73 \%$, believed that devices operating Microsoft Windows OS were the best while $69 \%$ stated that those having Google Android were more practical. A minority of participating teachers, $23 \%$, preferred mobile devices with Apple iOS.

\section{Discussion \& Conclusion}

As the results of the qualitative content analysis of the study suggest, some participating teachers believe that when students' use of mobile devices are more related to classroom activities, the instructors are more likely to encourage the use of mobile devices in the classrooms. This confirms previous research (Kuznekoff et al., 2015), which stresses the importance of the relevance of mobile devices' classroom application to the activities engaged in class. However, the findings of our study imply that activities such as contacting group members, while increasing collaboration, are less likely to be encouraged by instructors in the classroom.

Other findings indicate that devices operating Android are gaining popularity in the translation classrooms potentially due to their free open-source features, high reliability and freedom from licensing difficulties. It should be reminded that the present research is a small-scale exploratory study with limited participants and hence, we may not be able to generalize the findings to wider populations. More research should be conducted to verify our findings.

Furthermore, we know that the majority of current undergraduate university students have prior experience with mobile technology since their high school studies. This is best mentioned by Crompton (2013: 38) who describes high school students as 'power users' who do not like to 'power down' when they enter university. Given that most of the present undergraduate students are already familiar with and have used mobile devices since their high school days, it is very crucial for the teachers to adapt their teaching styles and strategies to accommodate to the new situation.

The importance of teaching styles and strategies is best portrayed by the framework that Richards \& Rodgers (2001) have presented for language teaching methodology. That framework can be adapted to teaching translation as well, in 
which a theory of the nature of language proficiency can be replaced by a theory of translation competence. When we consider most of the present translation competence models, which are 'multi-componential models', then the technological competence will be part of the approach that the instructors' adopt for teaching translation. Hence, our study requires that this technological competence include the use of mobile devices for teaching translation. Moreover, Richards \& Rodgers (2001) have emphasized the role of resources and instructional materials (e.g. mobile devices) both at the level of method design and classroom procedures (techniques, behaviors, practices). Therefore, the present researchers suggest that the application of technology in general and mobile devices in particular should be integrated into all aspects of the program.

Whereas using mobile devices in the classroom for the benefit of instruction is still a thorny issue in many academic circles, the findings of the present study highlight the potentials of mobile devices to create a positive impact on the translation classroom activities and underline the need for their systematic integration into the translation curriculum as part of the tools contributing to the development of technological competence.

\section{Acknowledgements}

This article is published with the support of the Universiti Sains Malaysia (USM) Fellowship.

\section{References}

Alcina, A. (2008). Translation technologies: Scopes, tools and resources. Target, 20(1), 79-102.

Crompton, H. (2013). The Benefits and Challenges of Mobile Learning. Learning \& Leading with Technology, 2013(September/October), 38-39.

Dörnyei, Z. (2007). Research methods in applied linguistics: Quantitative, qualitative and mixed methodologies. Oxford: Oxford University Press.

EMT Expert Group. (2009). The European Master's in Translation or EMT Expert Group for implementing a European reference framework for a Master's in translation throughout the European Union. Retrieved from http://ec.europa.eu/emt.

Farley, H., Murphy, A., Johnson, C., Carter, B., Lane, M., Midgley, W., Hafeez-Baig, A., Dekeyser, S., \& Koronios, A. (2015). How Do Students Use Their Mobile Devices to Support Learning? A Case Study from an Australian Regional University. Journal of Interactive Media in Education, 2015(1): 14, 1-13. doi: http://dx.doi.org/10.5334/jime.ar.

Foti, M. K., \& Mendez, J. (2014). Mobile Learning: How Students Use Mobile Devices to Support Learning. Journal of Literacy and Technology, 15(3), 58-78.

Jacobsen, W. C., \& Forste, R. (2011). The wired generation: Academic and social outcomes of electronic media use among university students. Cyberpsychology, Behavior, and Social Networking, 14, 275-280.

Kelly, D. (2005). A Handbook for Translator Trainers, Manchester: St Jerome Publishing, Translation Practices Explained: Volume 10, second edition.

Kuznekoff, J. H., Munz, S., \& Titsworth, S. (2015). Mobile Phones in the Classroom: Examining the Effects of Texting, Twitter, and Message Content on Student Learning. Communication Education, 64(3), 344-365. doi: 10.1080/03634523.2015.1038727.

Lam, P. \& Tong, A. (2012). Digital Devices in Classroom - Hesitations of Teachers-to-be. The Electronic Journal of eLearning, 2012(10): 4, 387-395. Retrieved from http://ejel.org.

Lepp, A., Barkley, J. E. \& Karpinski, A. C. (2015). The Relationship Between Cell Phone Use and Academic Performance in a Sample of U.S. College Students. SAGE Open, 2015(Jan-March), 1-9. doi: $10.1177 / 2158244015573169$.

PACTE Group. (2000). Acquiring Translation Competence: hypotheses and methodological problems of a research project. In Allison Beeby et al. (Eds.), Investigating Translation. Amsterdam: John Benjamins, 99-106.

PACTE Group. (2003). Building a translation competence model. In F. Alves (Ed.), Triangulating Translation: Perspectives in process oriented research, Amsterdam and Philadelphia: John Benjamins, 43-66.

PACTE Group. (2005). Investigating translation competence: conceptual and methodological issues. Meta, 50(2), 609619.

PACTE Group. (2007). Zum Wesen der Ubersetzungskompetenz: Grundlagen fur die experimentelle Validierung eines Uk-Modells. In G. Wotjak (Ed.), Quo vadis Translatologie? Ein halbes Jahrhundert universitärer Ausbildung von Dolmetschern und bersetzern in Leipzig: Rückschau, Zwischenbilanz und Perspektiven aus der Aussensicht, Berlin: Frank und Timme, 327-342.

PACTE Group. (2011). Results of the Validation of the PACTE Translation Competence Model: Translation Project and Dynamic Translation Index. In S. O'Brien (Ed.) IATIS Yearbook 2010, Londres: Continuum (acceptada y en prensa). 
Pearson Education. (2015). Student Mobile Device Survey 2015. Retrieved from http://pearsoned.com/wp.../2015Pearson-Student-Mobile-Device-Survey-College.pdf.

Richards, J. C. \& Rodgers, T. S. (2001). Approaches and methods in language teaching. Cambridge Language Teaching Library. Cambridge: CUP.

Roberts, R. (1984). Compétence du nouveau diplômé en traduction. In Traduction et Qualité de Langue. Actes du Colloque Société des traducteurs du Québec, Conseil de la langue française, Québec: Éditeur officiel du Québec, 172184.

Sanchez-Martinez, M. \& Otero, A. (2009). Factors associated with cell phone use in adolescents in the community of Madrid (Spain). CyberPsychology and Behavior, 12, 131-137.

Schäffner, C. \& Adab, B. (eds.) (2000). Developing Translation Competence, Amsterdam: John Benjamins.

Yeshi, T. \& Aagard, S. D. (2011). Cell Phones for College Teaching: A Literature Review. (June 10, 2011). Adult Education Research Conference, Paper 111. Retrieved from http://newprairiepress.org/aerc/2011/papers/111. 